Мазур Н. О., к.е.н., доцент, Ткачук А. В., магістр (Національний університет водного господарства та природокористування, м. Рівне)

\title{
РІВНЕНСЬКА ОБЛАСТЬ У ЗАГАЛЬНОНАЦІОНАЛЬНОМУ ВИМІРІ ЯКОСТІ ЖИТТЯ
}

Досліджено можливості оцінювання якості життя населення регіону на основі концепції людського розвитку. Здійснено порівняльний регіональний аналіз якості життя в Україні. Ідентифіковано роль Рівненської області у загальнонаціональному людському розвитку. Визначено основні стимулятори і дестимулятори якості життя населення у Рівненській області.

Ключові слова: індекс регіонального людського розвитку, людський розвиток, Рівненська область, якість життя населення.

Однією з головних характеристик рівня суспільного розвитку країн сучасним міжнародним співтовариством визнано якість життя. Для України, яка декларує себе як демократична соціальна держава, забезпечення гідної якості життя населення як беззаперечного критерію і необхідної умови людського розвитку, нині актуальне як на рівні усієї держави, так і для кожної адміністративно-територіальної одиниці.

У міжнародній практиці на основі визначених індикаторів постійно здійснюється оцінювання добробуту населення та оприлюднюються відповідні рейтинги країн. Зокрема, визначається індекс якості життя за такими методиками, як Better Life Index Організації економічного співробітництва та розвитку, Economist Intelligence Unit, Standard of Living and Quality of Life, індекс інтелектуального потенціалу суспільства, людський капітал на душу населення Всесвітнього Банку, коефіцієнт життєздатності населення, розроблений організацією ЮНЕСКО, щорічний рейтинг міст з найвищою якістю життя Mercer Human Resource Consulting, рейтинг найщасливіших країн lнституту Землі. Актуальність проблеми якості життя активізувала дослідження у цій сфері і серед вітчизняних науковців. Особливою методологічною глибиною характеризуються розробки щодо вимірювання якості життя колективу Інституту демографії та соціальних досліджень імені М.В. Птухи НАН України. Водночас, кожному конкретному регіону та населеному пунктові притаманні умови, здатні як покращувати, так і погіршувати якість життя населення у певній тери- 
торіально-адміністративній одиниці.

Тому постає завдання дослідження регіональних особливостей якості життя населення, зокрема ролі Рівненської області у формуванні загального рівня добробуту населення країни.

Якість життя, тобто умови існування людини, характеризують насамперед рівнем споживання товарів і послуг, а також соціальними результатами економічного і політичного розвитку: середньою тривалістю життя, рівнем захворюваності, умовами праці, соціальною захищеністю населення, поліпшенням соціального середовища, забезпеченням прав людини [1, С. 76]. У світовій практиці для характеристики якості життя найчастіше використовують індекс людського розвитку (ІЛР) - інтегральний показник, який визначається на основі трьох індикаторів: національного або валового внутрішнього продукту на душу населення, обчисленого в доларах паритету купівельної спроможності; тривалості життя у роках; рівня освіти населення, вираженого роками навчання та грамотністю дорослого населення у відсотках. Фахівцями Інституту демографії та соціальних досліджень імені М.В. Птухи Національної академії наук України за участю фахівців Державної служби статистики України розроблено вітчизняну методику визначення регіонального індексу людського розвитку (ІРЛР), що передбачає аналіз 33 показників, згрупованих у шість блоків: відтворення населення, соціальне становище, комфортне життя, добробут, гідна праця, освіта [2, С. 21-22; 3]. IPЛР є сумою субіндексів за кожним з шести блоків.

Динаміка IPЛР в Україні демонструє тенденції постійного зростання, однак для населення Рівненської області це не означає покращення якості життя. Якщо у 2007-2008 роках регіон знаходився на 13-му місці за рівнем людського розвитку, то згідно з останніми опублікованими даними область опинилася в рейтингу на шість сходинок нижче. Найвищий IPЛР характерний для Харківської, Чернівецької, Закарпатської та Львівської областей. Найнижчий рівень добробуту у Житомирській, Херсонській та Кіровоградській областях. Рівненська область посідає 19-е місце (рис. 1).

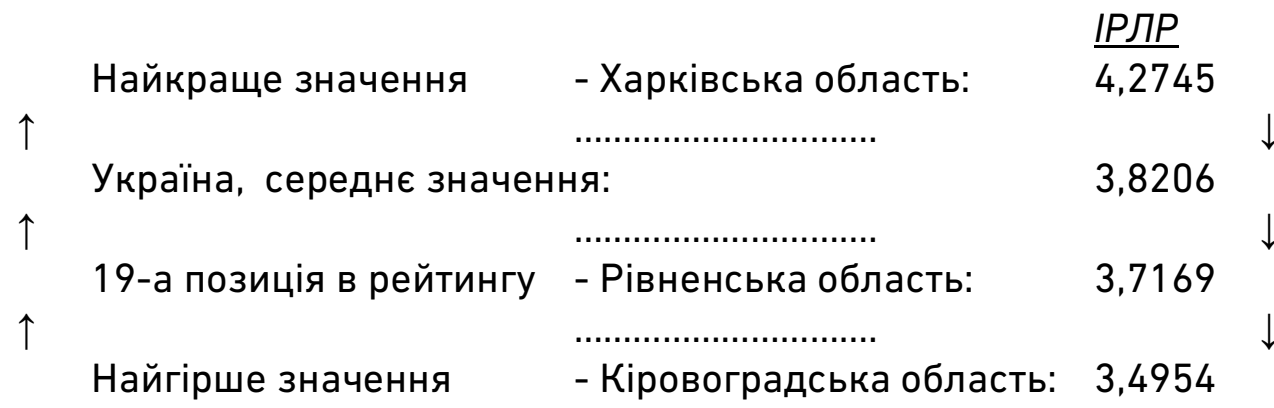

Рис. 1. Рівненська область у загальнонаціональному вимірі якості життя Джерело: розроблено авторами на основі [4] 
Визначені чинники диференційовано впливають на формування якості життя населення в регіоні.

Зокрема сучасні параметри відтворення населення - це та базова детермінанта, від якої залежать як темпи економічного поступу, так і можливості та пріоритети людського розвитку в країні. Водночас певні демографічні показники можна розглядати і як кінцеві індикатори результативності соціально-економічного розвитку [3].

Рівненській області, разом із Закарпатською, належть перше місце за народжуваністю. Стимуляторами зростання інтегрального IPЛP $€$ й решта демографічних показників. Загалом, найвищі рівні відтворення населення зафіксовано у західних областях (Чернівецькій, Львівській, Волинській, Рівненській, Тернопільській). Хоча за економічними показниками ці регіони дещо відстають, для них характерні вищі показники народжуваності, більша тривалість життя, нижча дитяча смертність. У промислово розвинених східних областях, а також у менш економічно розвиненій Житомирській області даний блок спричиняє зниження інтегрального індексу. Така ситуація склалася через незадовільний стан екології та здоров'я населення у промислових регіонах, а також більшу зорієнтованість населення на кар'єру і матеріальний добробут на відміну від західних сільськогосподарських регіонів, де інститут шлюбу та сім"ї відіграє вагомішу

роль (табл. 1).

Таблиця 1

Відтворення населення

\begin{tabular}{|l|c|c|c|c|}
\hline \multicolumn{1}{|c|}{ Показники } & Україна & $\begin{array}{c}\text { Рівненська обл. } \\
\text { (позиція в рей- } \\
\text { тингу) }\end{array}$ & $\begin{array}{c}\text { Найкраще } \\
\text { значення } \\
\text { (область) }\end{array}$ & $\begin{array}{c}\text { Найгірше } \\
\text { значення } \\
\text { (область) }\end{array}$ \\
\hline $\begin{array}{l}\text { Сумарний коефіцієнт } \\
\text { народжуваності, осіб } \\
\text { на 1 жінку }\end{array}$ & 1,506 & $\begin{array}{c}1,998 \\
(1)\end{array}$ & $\begin{array}{c}1,998 \\
\text { (Рівненська) }\end{array}$ & $\begin{array}{c}1,295 \\
\text { (Луганська) }\end{array}$ \\
\hline $\begin{array}{l}\text { Середня очікувана } \\
\text { тривалість життя при } \\
\text { народженні, } \\
\text { років }\end{array}$ & 71,37 & $\begin{array}{c}71,38 \\
(12)\end{array}$ & $\begin{array}{c}73,64 \\
\text { (Тернопільсь- } \\
\text { ка) }\end{array}$ & $\begin{array}{c}69,48 \\
\text { (Житомирська) }\end{array}$ \\
\hline $\begin{array}{l}\text { Смертність дітей у ві- } \\
\text { ці до 1 року, \% від } \\
\text { живонароджених }\end{array}$ & 0,8 & $\begin{array}{c}0,79 \\
(15)\end{array}$ & $\begin{array}{c}0,55 \\
\text { (Полтавська) }\end{array}$ & $\begin{array}{c}1,14 \\
\text { (Донецька) }\end{array}$ \\
\hline $\begin{array}{l}\text { Имовірність } \\
\text { чоловіків дожити до } \\
65 \text { років }\end{array}$ & 0,8026 & 0,7990 & $\begin{array}{c}0,8323 \\
\text { (Чернівецька) }\end{array}$ & $\begin{array}{c}0,7752 \\
\text { (Житомирська) }\end{array}$ \\
\hline $\begin{array}{l}\text { Имовірність жінок } \\
\text { дожити до 65 років }\end{array}$ & 0,9123 & 0,9114 & $\begin{array}{c}0,9229 \\
\text { (Львівська) }\end{array}$ & $\begin{array}{c}0,8996 \\
\text { (Закарпатська) }\end{array}$ \\
\hline
\end{tabular}

Джерело: розроблено авторами на основі $[4 ; 5]$ 
Посилення соціальної нестабільності та напруженості у суспільстві зумовлено обмеженням можливостей частини населення у задоволенні потреб охорони здоров'я, освіти, культури, інших соціальних послуг. Це провокує погіршення фізичного, духовного та психічного здоров'я людей. Посилення соціальної нестабільності та напруженості в суспільстві спричиняє розповсюдження таких негативних явищ, як злочинність, проституція, соціальне сирітство, а також соціальних хвороб: туберкульозу, алкоголізму, наркоманії [3]. У Рівненській області зафіксовано порівняно невелику кількість самогубств, хворих туберкульозом та психічними розладами, дітей-сиріт. Однак регіон знаходиться на останньому місці за коефіцієнтом підліткової народжуваності, що свідчить про поширення девіантної поведінки серед молоді (табл. 2).

Таблиця 2

Соціальне становище

\begin{tabular}{|c|c|c|c|c|}
\hline Показники & Україна & $\begin{array}{c}\text { Рівненська } \\
\text { обл. } \\
\text { (позиція в } \\
\text { рейтингу) }\end{array}$ & $\begin{array}{l}\text { Найкраще } \\
\text { значення } \\
\text { (область) }\end{array}$ & $\begin{array}{c}\text { Найгірше зна- } \\
\text { чення } \\
\text { (область) }\end{array}$ \\
\hline $\begin{array}{l}\text { Кількість хворих із впе- } \\
\text { рше встановленим діаг- } \\
\text { нозом активного тубер- } \\
\text { кульозу, на } 10000 \text { насе- } \\
\text { лення }\end{array}$ & 6,77 & $\begin{array}{c}6,28 \\
(9)\end{array}$ & $\begin{array}{c}4,57 \\
\text { (Чернівецька) }\end{array}$ & $\begin{array}{c}9,63 \\
\text { (Херсонська) }\end{array}$ \\
\hline $\begin{array}{l}\text { Кількість хворих із впе- } \\
\text { рше встановленими роз- } \\
\text { ладами психіки, на } \\
10000 \text { населення }\end{array}$ & 22,56 & $\begin{array}{c}19,45 \\
(9)\end{array}$ & $\begin{array}{c}13,99 \\
\text { (Чернівецька) }\end{array}$ & $\begin{array}{c}39,6 \\
\text { (Харківська ) }\end{array}$ \\
\hline $\begin{array}{l}\text { Кількість дітей-сиріт та } \\
\text { дітей, які потребували } \\
\text { батьківського піклуван- } \\
\text { ня, на } 10000 \text { населення }\end{array}$ & 14 & $\begin{array}{c}12,41 \\
(10)\end{array}$ & $\begin{array}{c}7,37 \\
\text { (Тернопільська) }\end{array}$ & $\begin{array}{l}\text { 21,59 (Кірово- } \\
\text { градська) }\end{array}$ \\
\hline $\begin{array}{l}\text { Коефіцієнт підліткової } \\
\text { народжуваності (15- } \\
19 \text { років), на } 1000 \text { жінок } \\
\text { відповідного віку }\end{array}$ & 45 & $\begin{array}{l}60,5 \\
(25)\end{array}$ & $\begin{array}{c}37,6 \\
\text { (Сумська) }\end{array}$ & $\begin{array}{c}\text { 60,5 } \\
\text { (Рівненська) }\end{array}$ \\
\hline $\begin{array}{l}\text { Кількість померлих від } \\
\text { навмисного самоушко- } \\
\text { дження, на } 10000 \text { насе- } \\
\text { лення }\end{array}$ & 2,06 & $\begin{array}{l}1,51 \\
(6)\end{array}$ & $\begin{array}{c}0,64 \\
\text { (Львівська) }\end{array}$ & $\begin{array}{c}3,28 \\
\text { (Херсонська) }\end{array}$ \\
\hline
\end{tabular}

Джерело: розроблено авторами на основі $[4 ; 5]$

Соціальне середовище більше залежить від рівня соціальної захищеності та свідомості громадян, а не від економічної стабільності. Найкраща ситуація спостерігається у регіонах з вищим розвитком культурно-соціальної сфери, для яких характерна й вища задоволе- 
ність життям. Найкраще соціальне становище характерне для Чернівецької, Львівської та Закарпатської областей, найгірше - для Кіровоградської, Житомирської і Херсонської.

Комфортність проживання у регіоні характеризується забезпеченістю населення житлом, враховуючи рівень його облаштування, розвитком соціальної інфраструктури та станом навколишнього природного середовища [3]. При цьому на сьогодні забезпеченість житлом та рівень його благоустрою часто $є$ одним з головних стимуляторів якості життя населення на рівні конкретної територіальноадміністративної одиниці. Для України характерна краща забезпеченість населення житлом у сільській місцевості, хоча комфортніші умови проживання - у містах. 3 розвитком процесів урбанізації, показники комфортності життя знижуються, оскільки темпи збільшення чисельності міських жителів не відповідають темпам розвитку інфраструктури міст. Невисокий рівень комфорту характерний для Кіровоградської, Житомирської та Волинської областей. Найкращі показники притаманні для Закарпатської та Херсонської областей. У високоурбанізованих регіонах вища забезпеченість населення житлом і, водночас, низький рівень комфортності життя в селі. У Рівненській області спостерігаємо один з найнижчих показників комфортності життя (табл. 3).

Таблиця 3

Комфортне життя

\begin{tabular}{|c|c|c|c|c|}
\hline Показники & Україна & $\begin{array}{c}\text { Рівненська } \\
\text { обл. (позиція в } \\
\text { рейтингу) }\end{array}$ & $\begin{array}{c}\text { Найкраще зна- } \\
\text { чення } \\
\text { (область) }\end{array}$ & $\begin{array}{c}\text { Найгірше зна- } \\
\text { чення } \\
\text { (область) }\end{array}$ \\
\hline $\begin{array}{l}\text { Забезпеченість насе- } \\
\text { лення житлом у місь- } \\
\text { ких поселеннях, м² на } \\
1 \text { жителя }\end{array}$ & 22,1 & $\begin{array}{c}18 \\
(25)\end{array}$ & $\begin{array}{c}26,2 \\
\text { (Київська) }\end{array}$ & $\begin{array}{c}18 \\
\text { (Рівненська) }\end{array}$ \\
\hline $\begin{array}{l}\text { Питома вага квартир у } \\
\text { сільській місцевості, } \\
\text { обладнаних каналіза- } \\
\text { цією, \% }\end{array}$ & 23,3 & $\begin{array}{l}21,4 \\
(17)\end{array}$ & $\begin{array}{c}56,9 \\
\text { (Закарпатська) }\end{array}$ & $\begin{array}{c}8,9 \\
\text { (Житомирська) }\end{array}$ \\
\hline $\begin{array}{l}\text { Питома вага квартир у } \\
\text { сільській місцевості, } \\
\text { обладнаних газопоста- } \\
\text { чанням, \% }\end{array}$ & 83,9 & $\begin{array}{c}74 \\
(22)\end{array}$ & $\begin{array}{c}97,9 \\
\text { (АР Крим) }\end{array}$ & $\begin{array}{c}50,7 \\
\text { (Донецька) }\end{array}$ \\
\hline $\begin{array}{l}\text { Планова ємність амбу- } \\
\text { латорно-поліклінічних } \\
\text { закладів, на } 10000 \text { на- } \\
\text { селення }\end{array}$ & 88 & $\begin{array}{l}82,2 \\
(20)\end{array}$ & $\begin{array}{c}109,8 \\
\text { (Чернігівська) }\end{array}$ & $\begin{array}{c}72,5 \\
\text { (Закарпатська) }\end{array}$ \\
\hline $\begin{array}{l}\text { Обсяг наданих насе- } \\
\text { ленню послуг, тис. грн } \\
\text { на } 1 \text { особу }\end{array}$ & 7,86 & $\begin{array}{l}2,59 \\
(19)\end{array}$ & $\begin{array}{c}22,52 \\
\text { (Закарпатська) }\end{array}$ & $\begin{array}{c}1,79 \\
\text { (Чернівецька) }\end{array}$ \\
\hline
\end{tabular}

Джерело: розроблено авторами на основі [4; 5] 
Для регіону характерна найнижча забезпеченість житлом у містах, низька ємність лікарняних закладів, низький рівень обладнання газо- та водопостачанням у сільській місцевості.

Рівень добробуту населення $\epsilon$ тією матеріальною основою, яка не тільки забезпечує якісний розвиток, але й дає змогу обирати його напрямок [3]. Бідність як соціально-економічна категорія нерозривно пов'язана з низькою тривалістю життя, низьким рівнем освіти і, відповідно, з низькими можливостями ефективної реалізації особистої трудової активності. За економічними показниками Рівненщина значно відстає від багатьох областей України. Для регіону характерні один $з$ найвищих показників чисельності населення з доходами нижче прожиткового мінімуму, один з найнижчих ВРП; населення майже не купує нерухомість, а кількість продуктових кошиків, яку можна придбати на середній дохід, більше ніж на 20\% менша за середнє значення в країні (табл. 4).

Таблиця 4

Добробут населення

\begin{tabular}{|c|c|c|c|c|}
\hline Показники & Україна & $\begin{array}{c}\text { Рівненська } \\
\text { обл. } \\
\text { (позиція в } \\
\text { рейтингу) }\end{array}$ & $\begin{array}{l}\text { Найкраще } \\
\text { значення } \\
\text { (область) }\end{array}$ & $\begin{array}{l}\text { Найгірше } \\
\text { значення } \\
\text { (область) }\end{array}$ \\
\hline $\begin{array}{l}\text { Частка населення із сере- } \\
\text { дньодушовими доходами, } \\
\text { нижчими за прожитковий } \\
\text { мінімум, \% від загальної } \\
\text { чисельності населення ві- } \\
\text { дповідної групи }\end{array}$ & 8,4 & $\begin{array}{l}16,9 \\
(24)\end{array}$ & $\begin{array}{c}3,6 \\
\text { (Харківська) }\end{array}$ & $\begin{array}{c}17,2 \\
\text { (Тернопільська) }\end{array}$ \\
\hline $\begin{array}{l}\text { Кількість мінімальних про- } \\
\text { дуктових кошиків, які мо- } \\
\text { жна придбати на серед- } \\
\text { ньодушовий дохід }\end{array}$ & 23,6 & $\begin{array}{l}18,7 \\
(21)\end{array}$ & $\begin{array}{c}27,1 \\
\text { (Донецька) }\end{array}$ & $\begin{array}{c}16,2 \\
\text { (Закарпатська) }\end{array}$ \\
\hline $\begin{array}{l}\text { Валовий регіональний } \\
\text { продукт у розрахунку на } 1 \\
\text { особу, грн }\end{array}$ & 33473 & $\begin{array}{c}19003 \\
(22)\end{array}$ & $\begin{array}{c}46333 \\
\text { (Дніпро- } \\
\text { петровська) }\end{array}$ & $\begin{array}{c}15154 \\
\text { (Чернівецька) }\end{array}$ \\
\hline
\end{tabular}

Джерело: розроблено авторами на основі [4; 5]

Низькі значення економічних показників спостерігаємо також у Закарпатській, Чернівецькій, Волинській та Житомирській областях, найвищі - у Харківській. Тобто передові позиції належать промислово орієнтованим, економічно розвиненим регіонам. Для аграрних областей притаманний значно нижчий рівень доходів населення. Тому для Рівненської області цей блок $є$ суттєвим дестимулятором при обчисленні ІРЛР.

Дослідження гідної праці населення передбачає аналіз показників, пов'язаних з умовами та оплатою праці. Зайнятість, як основна 
форма реалізації економічної активності населення і засіб для забезпечення його добробуту, є однією з головних характеристик людського розвитку у регіоні. Захищеність зайнятого населення характеризується умовами праці, що не відповідають санітарно-гігієнічним нормам, та рівнем охоплення соціальним страхуванням [3]. Рівненська область посідає досить низькі позиції в загальнонаціональному рейтингу за показниками цього блоку оцінювання якості життя (табл. 5).

Таблиця 5

Гідна праця

\begin{tabular}{|c|c|c|c|c|}
\hline Показники & Україна & \begin{tabular}{|c|} 
Рівненська \\
обл. (позиція в \\
рейтингу)
\end{tabular} & $\begin{array}{c}\text { Найкраще зна- } \\
\text { чення } \\
\text { (область) }\end{array}$ & $\begin{array}{l}\text { Найгірше } \\
\text { значення } \\
\text { (область) }\end{array}$ \\
\hline Рівень зайнятості, \% & 60,3 & $\begin{array}{l}59,6 \\
(15)\end{array}$ & $\begin{array}{c}62,3 \\
\text { (АР Крим) }\end{array}$ & $\begin{array}{l}\text { 55,4 (Івано- } \\
\text { Франківська) }\end{array}$ \\
\hline Рівень безробіття, \% & 7,2 & $\begin{array}{l}9,4 \\
(24) \\
\end{array}$ & $\begin{array}{c}5,3 \\
\text { (Одеська) } \\
\end{array}$ & $\begin{array}{c}\text { 9,4 (Тернопільсь- } \\
\text { ка) }\end{array}$ \\
\hline $\begin{array}{l}\text { Частка працівників, } \\
\text { які працюють в умо- } \\
\text { вах, що не відпові- } \\
\text { дають санітарно- } \\
\text { гігієнічним нормам, } \\
\%\end{array}$ & 29,5 & $\begin{array}{l}30,2 \\
(21)\end{array}$ & $\begin{array}{c}10 \\
\text { (Закарпатська) }\end{array}$ & $\begin{array}{c}\text { 48,7 } \\
\text { (Луганська) }\end{array}$ \\
\hline $\begin{array}{l}\text { Співвідношення се- } \\
\text { редньої та мінімаль- } \\
\text { ної заробітної плати, } \\
\text { одиниць }\end{array}$ & 2,85 & $\begin{array}{l}2,48 \\
(11)\end{array}$ & $\begin{array}{c}3,27 \\
\text { (Донецька) }\end{array}$ & $\begin{array}{c}2,06 \\
\text { (Тернопільська) }\end{array}$ \\
\hline $\begin{array}{l}\text { Частка працівників, } \\
\text { які отримали заробі- } \\
\text { тну плату до } 1500 \\
\text { грн, \% }\end{array}$ & 6,7 & $\begin{array}{c}7 \\
(15)\end{array}$ & $\begin{array}{c}3,5 \\
\text { (Донецька) }\end{array}$ & $\begin{array}{c}10,4 \\
\text { (Київська) }\end{array}$ \\
\hline
\end{tabular}

Джерело: розроблено авторами на основі $[4 ; 5]$

Рівненська область знаходиться на 24-му місці за рівнем безробіття, який більше ніж на $2 \%$ вищий порівняно із середнім значенням в державі. Високий рівень оплати праці спостерігається лише у м. Вараш, де основною сферою зайнятості $€$ атомна енергетика. Для інших адміністративно-територіальних одиниць області характерна низька заробітна плата поряд із постійно зростаючим рівнем витрат та однією з найвищих часток працівників, зайнятих у неналежних умовах праці. Гірша ситуація склалася тільки в регіонах, у яких зосереджені підриємства важкої та видобувної промисловості. Однак у цих областях спостерігаємо найвищі значення показників, пов'язаних з оплатою праці. Загалом краще значення даного часткового індексу характерне для східних регіонів, де рівень зайнятості та оплата праці значно вищі. 
Останній блок показників для характеристики якості життя пов'язаний з ключовим елементом забезпечення сталого розвитку людського потенціалу - рівнем освіти. Найгірше в області склалася ситуація з дошкільною освітою: лише $57 \%$ дітей забезпечені місцями в дитячих садках (на 5\% нижче від середнього значення в державі). Загальноосвітні та вищі навчальні заклади дещо краще виконують свої функції - 10-е місце в рейтингу (табл. 6).

Таблиця 6

Освіта

\begin{tabular}{|c|c|c|c|c|}
\hline Показники & Україна & $\begin{array}{l}\text { Рівненська } \\
\text { обл. (позиція } \\
\text { в рейтингу) }\end{array}$ & $\begin{array}{c}\text { Найкраще } \\
\text { значення } \\
\text { (область) }\end{array}$ & $\begin{array}{l}\text { Найгірше } \\
\text { значення } \\
\text { (область) }\end{array}$ \\
\hline $\begin{array}{l}\text { Охоплення дошкільни- } \\
\text { ми навчальними закла- } \\
\text { дами, \% до чисельності } \\
\text { дітей відповідного віку }\end{array}$ & 62 & $\begin{array}{l}57 \\
(8)\end{array}$ & $\begin{array}{c}73 \\
\text { (Донецька) }\end{array}$ & $\begin{array}{c}39 \\
\text { (Івано- } \\
\text { Франківська) }\end{array}$ \\
\hline $\begin{array}{l}\text { Охоплення загальною } \\
\text { середньою освітою ді- } \\
\text { тей шкільного віку, \% } \\
\end{array}$ & 83 & $\begin{array}{l}83,5 \\
(10)\end{array}$ & $\begin{array}{c}90,5 \\
\text { (Київська) }\end{array}$ & $\begin{array}{c}78,9 \\
\text { (Вінницька) }\end{array}$ \\
\hline $\begin{array}{l}\text { Частка студентів BН3 III- } \\
\text { IV рівнів акредитації у } \\
\text { загальній чисельності } \\
\text { працездатного насе- } \\
\text { лення, \% }\end{array}$ & 6,08 & $\begin{array}{l}4,44 \\
(10)\end{array}$ & $\begin{array}{c}10,74 \\
\text { (Харківська) }\end{array}$ & $\begin{array}{c}1,96 \\
\text { (Кірово- } \\
\text { градська) }\end{array}$ \\
\hline
\end{tabular}

\section{Джерело: розроблено авторами на основі [4; 5]}

Таким чином, найбільш вагомим внеском Рівненської області у рівень загальнонаціонального людського розвитку слід вважати позитивні тенденції відтворення населення. Основними дестимуляторами якості життя в регіоні є економічні показники (рис. 2).

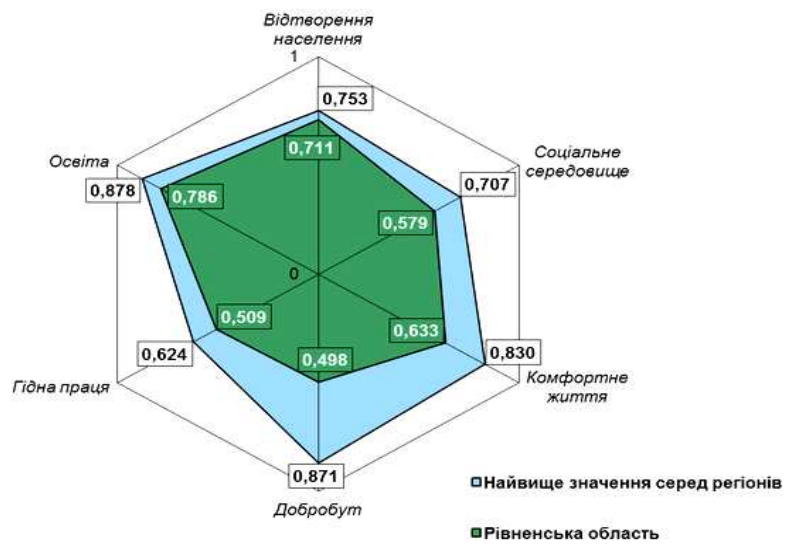

Рис. 2. Порівняльна оцінка індикаторів людського розвитку Рівненської області [4]

Якість життя населення - інтегральне поняття, яке передбачає аналіз усіх сфер життєдіяльності суспільства. Підвищення якості 
життя є критерієм і необхідною умовою людського розвитку. Аналіз тенденцій якості життя на регіональному рівні дає змогу усунути міжрегіональні диспропорції розвитку та формувати державну соціальну політику, враховуючи територіальні відмінності та найбільш проблемні сфери у забезпеченні належного рівня добробуту населення.

У результаті оцінювання якості життя у Рівненській області виявлено основні стимулятори та дестимулятори добробуту населення. Для регіону характерна одна з найкращих демографічних ситуацій в Україні: донедавна - додатній природний приріст, зростання чисельності населення, низький середній вік, переважання молоді в структурі населення. Хоча помітні й негативні тенденції, зокрема, від'ємне сальдо міграції. Основнимм дестимуляторами людського розвитку області є показники з економічного становища. Забезечення стандартів гідної праці, добробуту та комфортного життя - основні резерви зростання якості життя в регіоні.

Адекватне оцінювання якості життя здатне сприяти визначенню найбільш проблемних сфер та прийняттю ефективних управлінських рішень за чітко визначеними аспектами, досягненню світових показників добробуту на рівні як усієї держави, так і кожної територіально-адміністративної одиниці.

1. Завіновська Г. Т. Економіка праці : навч. посібник. К. : КНЕУ, 2003. 300 с. 2. Вимірювання якості життя в Україні : аналітична доповідь / Лібанова Е. М., Гладун О. М., Лісогор Л. С. та ін. К. : 2013. 3. Методика вимірювання регіонального людського розвитку. Київ, 2012. URL: http://www.idss.org.ua/\#. (дата звернення : 08.10.2018). 4. Офіційний сайт Інституту демографії та соціальних досліджень імені М. В. Птухи Національної академії наук України. URL: http://www.idss.org.ua/ukr_index.html (дата звернення : 08.10.2018). 5. Офіційний сайт Державної служби статистики України. URL: http://ukrstat.gov.ua/ (дата звернення : 08.10.2018).

\section{REFERENCES :}

1. Zavinovska H. T. Ekonomika pratsi : navch. posibnyk. K. : KNEU, 2003. 300 s. 2. Vymiriuvannia yakosti zhyttia v Ukraini : analitychna dopovid / Libanova E. M., Hladun O. M., Lisohor L. S. ta in. K. : 2013. 3. Metodyka vymiriuvannia rehionalnoho liudskoho rozvytku. Kyiv, 2012. URL: http://www.idss.org.ua/\#. (data zvernennia : 08.10.2018). 4. Ofitsiinyi sait Instytutu demohrafii ta sotsialnykh doslidzhen imeni M. V. Ptukhy Natsionalnoi akademii nauk Ukrainy URL: http://www.idss.org.ua/ukr_index.html (data zvernennia : 08.10.2018). 5. Ofitsiinyi sait Derzhavnoi sluzhby statystyky Ukrainy. URL: http://ukrstat.gov.ua/ (data zvernennia : 08.10.2018).

Рецензент: д.е.н., професор Савіна Н. Б. (НУВГП) 
Mazur N. O., Candidate of Economics (Ph. D.), Associate Professor, Tkachuk A. V., Master (National University of Water and Environmental Engineering, Rivne)

\section{RIVNE REGION IN NATIONWIDE MEASUREMENT OF LIFE QUALITY}

The modern international community has recognized the quality of life as one of the main characteristics of the level of social countries development. The quality of life is an integral concept that involves an analysis of all spheres of society's life. Special conditions can both improve and worsen the quality of life of the population inherent in each specific region and settlement. Therefore, the task of studying regional features of quality of life, in particular the role of Rivne region in shaping the general level of welfare of the population of Ukraine, appears.

The possibilities of estimating the quality of life of the population of the region on the basis of the Concept of Human Development are investigated. A comparative regional analysis of the quality of life in Ukraine is carried out. The role of providing national human development is identified. The main stimulators and destimulators of the quality of life of the population in the Rivne region are determined. The region is characterized by one of the best demographic situations in Ukraine. The main destimulators of the human development of the region are indicators of the economic position. Improving the quality of life is a criterion and a prerequisite for the human development. Keywords: Regional Human Development Index, human development, Rivne region, quality of life.

Мазур Н. А., к.э.н., доцент, Ткачук А. В., магистр (Национальный университет водного хозяйства и природопользования, г. Ровно)

\section{РОВЕНСКАЯ ОБЛАСТЬ В ОБЩЕНАЦИОНАЛЬНОМ ИЗМЕРЕНИИ КАЧЕСТВА ЖИЗНИ}

Исследованы возможности оценки качества жизни населения в регионе на основе концепции человеческого развития. Осуществлен сравнительный региональный анализ качества жизни в Украине. Идентифицирована роль Ровенской области в общенациональном человеческом развитии. Определены основные стимуляторы и дестимуляторы качества жизни населения в Ровенской области. Ключевые слова: индекс регионального человеческого развития, человеческое развитие, Ровенская область, качество жизни населения. 